\title{
PRODUCT MANAGEMENT, CONTROLLING AND LOGISTICS AT AGRICULTURE AND FOOD MANUFACTURING COMPANIES
}

\author{
Dr. habil. Ph.D. József Gál* - Éva Kmoskó** \\ *associate professor, University of Szeged, Faculty of Engineering \\ ** controlling manager, Villeroy \& Boch Magyarorszag Kft.
}

\begin{abstract}
How to understand logistics in agro-food business? Logistic activities considerably changed in the last few years. The original aim of satisfying quantity needs has been followed by the logistic activity which meets the market's requirements, aims at satisfying the individual needs instead of standardized solutions, maximal the additional values, and finally, which gives a complex service. You can find special process of it in agriculture and food industry. These together mean a significant challenge for this profession. In our paper we try to understand methodology of logistics in agro-food business.
\end{abstract}

\section{Introduction}

The most important purpose of the companies is making the most of the profitproductive capacity of the invested capital that manifests itself in the increase of the company's value. It is the same in agriculture and food industry as well, but has some special components in its process. Claims lay by owners - profit, dividend and share - set the management a serious task. We can be witnesses of continuous changes in the framework of the market economy in the fields of products and services, also in the labor-, money-, and capital markets. That is why it is not a negligible question to answer that what inner conditions our firm has, that is what kind of combination and organization structure of the product sources it has. That is what can influence the quality of answers and reactions to the changes of the outside environment. (Halászné 1998) In the agriculture you can calculate with seasons, long production circle and costs at first and much later incomes.

During reactions the relationship between the company and its outside environment is continuously changing. However, it is not the same at all whether we can get closer to or further from the market claims by our reaction. (By market claims we mean the ones of the consumers, owners, creditors, employees and suppliers.) Controlling, which provides a suitable tool for realization of the required activities, is destined for supporting this above mentioned aim. (Hargitai S. 1996, Körmendi L. - Tóth A. 1998) In the agriculture controlling methodology is new, small farms do not use it to plan and check their operation. The situation is better in food industry which shows strategic and operative controlling regularly like other industrial sectors.

By coordinating the given planning, analyzing and accounting elements, controlling can create an informatics system with the help of which the different structural parts are integrated into one single unit oriented on decision and management. It opens up new vistas to mobilize the inner forces in the interest of the strategic objects.

Each company has a different controlling system, but what they have in common is that the continuous process of planning-controlling is indispensable for their successful operation. This process explores causal relations, predicts economical consequences, so it transforms the operative analytical assessments into direct information for the management. 


\section{Informational system of logisties in agro-food business}

Information systems are able to store the customers' needs, to compare them with the available stores (with regard of material, goods and final product), to make a manufacturing plan, to decide over the additional material and product need, to follow the processes of store keeping, outfitting and packaging, to fix goods delivery and finally, to evaluate all these processes. (Forgács A. 2007) Information system, data management is not very hard in Hungary. Agricultural enterprises have typically PC-based systems, but connections are rarely among them. There are many new technologies, like GPS and networking (intranet, extranet and internet) but only mobile phones and sometimes fax and internet on a PC can be found. Many farms have no any computers and other modern informatics technologies.

It is impossible to collect, treat and process information without the appropriate information system. Most of the companies operate different subsystems to follow the reserve economy, marketing, and the processes of production, accounting and controlling. Logistics is exactly the field where these data have to be administrated as a system and these processes have to be made transparent and controllable because it is essential for the efficient operation.

With the help of the well-operating information systems the effort of the employees can be rationalized since the time-consuming check of different subsystem data can be eliminated. It is interesting how to plan agricultural production mainly vegetables and fruits for market have forecasted demands months before taking notice of climate.

Following the supply movement through the different subsystems makes the flow of both logistic and controlling information simple and efficient which has a direct effect on the quality of services provided for customers. The daily bookkeeping of accounting and controlling data supports the current data process, offers the opportunity of the quick intervention.

\section{Coincidence of logistics and controlling}

One of the controlling tasks is to evaluate and support the logistic activity. For this, controlling provides logistics with tools for analysis and evaluation, and an appropriately structured flow of information from the point of view the functional approach.

Connecting points

- cost calculation and cost analysis of the logistic activity, focusing on the fields of possible intervention,

- calculations on the investment-profitability with regards to the logistic tools,

- store-controlling,

- simulations, calculations,

- following the value production in the field of logistics, process analysis of the logistic chain of purchase-production-product treatment- satisfying customers' claims. (Figure 1)

'The major aim of logistic controlling as a 'service' is to support the objects and strategies of the given company with its collected feedback, to process and apply methods for checking their parameters, and cooperating this way, to support the optimal organization, control and the necessary financial background of the logistic processes.' (Knoll I. 2003) 


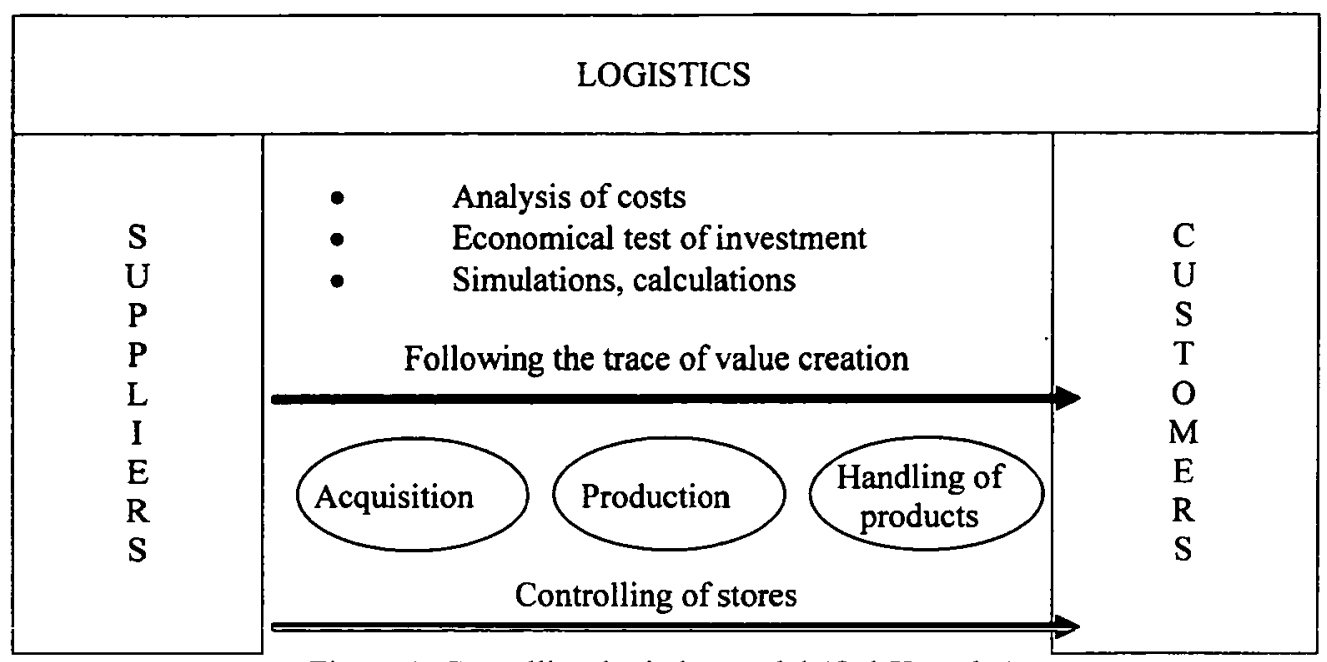

Figure 1: Conrolling-logistics model (Gal-Kmosko)

Logistic controlling within the company organization can be operated in the following ways

a) given departments or parts of departments within the controlling organization perform this duty,

b) given departments or part of departments within the logistic organization perform this duty,

c) departments or part of departments within both of the logistic and controlling organizations perform this duty together.

When we choose from these three alternatives it is important to consider the size of the company, the size and complexity of the logistic activity, the size and tasks of the controlling system, the scope of responsibilities and authority within the company. Solution c) can operate when the controlling system is active in the fields of those factors which influence the effectiveness of the company, while logistics is busy in the fields of those activities which improve its own processes. This way cost calculation and analysis; calculations on the investment-profitability, store-controlling, following the value-production belong to the duties and authorities of controlling, while analysis of the chain of purchase-productionproduct treatment-satisfying customers' claims mean duty in the field of logistics. Close cooperation and the appropriate flow of information between the two areas provide a successful logistic controlling activity.

\section{Cost calculation, cost analysis of the agricultural logistic activity, focus on the fields on intervention}

The value increasing conception is specified in strategic objects, in the forms of long-, and short-range plans, and at the same time the contribution of each responsibility areas to the realization of the company aims is put down. The controlling system arranges for the control - oriented on productiveness and liquidity - according to the plans, for the takeover of the controlling-philosophy. In this respect controlling undertakes an operative duty in the 
takeover of the conception and in the interest of which it makes the tools of reporting and planning available to the whole company.

\subsection{An example for the planning process:}

In the first stage of operative planning is a marketing plan, which focuses on the market needs, is made that estimates the salable quantities with regards to each product group. The quantity plan is followed by a price plan with the help of which the natural data are formed into values or return from sales. For further planning it is essential to divide the quantity for sale into self-made store and goods from outside suppliers.

Considering the store available at the beginning of the planning period both the quantity to be purchased and the quantity to be produced by the company can be calculated which is put down in the purchase and production plan.

At this point it is indispensable to examine the capacity plans both in short and longrange and to compare them with the quantity plan. It may be necessary to implement enlarging investments in addition to the supplement of the given capacities. We can apply for it from the investment frame determined in the strategy plan by presenting the calculations on profitability.

The investment plan is built up on the basis of the winning projects which influence the liquidity-, and cost plans. The given tools and the planned investments determine the value decrease plan of each responsibility area. This plan is part of the fixed expenses. Value decreasing description of logistic buildings, machines, equipments and vehicles should be indicated under this category of expenditure.

A human labor force-plan is needed in addition to the establishment of tool conditions, which includes the requirements on staff numbers and other professional factors.

Personal expenditure plan shows the wages, fringe benefits, work clothes and other personal payments for the workers who provide the logistic operation.

Different services and other expenses are settled after a consultation with those who are responsible for costs, making use of the characteristic features of the responsibility area. The following expenses are accounted here: invoices of outside carriers and different suppliers, IT-developments and costs of telecommunications.

It is practical to sort the expenditures on material into both the direct and indirect cost categories and to plan the direct items flexibly. By direct expenditure on material I mean the material consumption in connection with packaging and fitting which is product-dependent. At this cost category the additional-value creation has to be examined and not the sheer cost. Standard costs calculated on the given product group can create a perfect ground to measure performance, since comparing the actual costs with the given standard cost can provide the controller with a flexible plan-fact analyzing tool. Standard cost calculation can be expanded to the other expenditure categories, and this way we can standardize the cost of the whole working process.

In the agriculture you can find some special requirements. There are climate impacts which can help you to plan your production circle but the same time means risks as well. Seasonality is a big problem. Sometimes you have weakness in human resources on the other hand it is not a good idea to keep big number of employee whole year. Do not forget grass crop rotation when you plan your composition of your plants. About animals and meet and milk production the situation analogous. During life cycle of livestock you must calculate unproductive times. This situation is modified by fluctuating market demands and input of producers in food industry. 
The expenditure plan made this way can serve as a base to measure the effectiveness of the logistic processes, and by evaluating the facts, it can help indicate the areas to be corrected and draw up a measure plan.

\section{Conclusion}

In agro-food business there are much more risks than industrial production. Using methodology and practice of product management, controlling and logistics is possible, but you can find special bottleneck belonging on climate. Calculations are on the investmentprofitability with regards to the logistic tools are necessary. The proactive activity of controlling is realized by simulations and calculations in connection with future. The question „Shall I produce it myself or make it produced by somebody else?" has an important role in the field of logistics, that is whether the company itself produce the products, services; or its capacity, its human and other resources, their cost and other factors support outside purchase, or outsourcing of the given activity.

5.1. Logistic terms of this question can be the followings:

- $\quad$ self-made product or purchase from other source;

- $\quad$ activity of assembling, packaging for further production (like canning factories);

- activity of freight arrangements;

- $\quad$ agro-supply chain management;

- transportation;

- administration.

Following the value production in the field of logistics you can see process analysis of the logistic chain of purchase-production-product treatment-satisfying customers' claims.

Production and purchase plan induced by the customer's claim can be made by programming the practical experiences, by using the collected, systematic facts; or by working up perfectly new information.

I have mentioned that it is important to follow the movements of reserves. The accurate and high-quality work of suppliers gives the basis of the proper activity. Essentially important factors are: order, accept and the suitable treatment of inputs; their structured, accurate storage and the conveyance of materials. Optimal of these processes is the fundamental task of the logistic process organization, and controlling can help it with cost calculating tools. Areas of optimal are decrease of time between order and transportation, minimal of the way and number of the conveyance of goods, decrease its speed, optimal of transit time.

\subsection{Customers' claims and their satisfaction}

Nowadays, the controlling activity focused on customers and their claims are given a key-role. Although, the marketing and financial controlling are focusing on the real return from sales and the financial execution for goods and services, we should not leave our own performance out of consideration. From the point of view of logistics we have to measure and evaluate transportation, its accuracy (time and content), its quality and the customers' satisfaction. The evaluating system can include post-correction of a specific customer claim, evaluation of a not 100 per cent performance. 
It is certain that nowadays one of the tokens of the economical and financial success is the high-level controlling, product management and logistic system. Field growing and animal husbandry have extra risks, therefore much more complicated to plan and produce according to forecast. Costs incurred immediately and turnover come later than in normal industrial production. The situation is more complicated, because agricultural production joins food industrial production or market sells. Without modern informatics it is impossible mission to organize and realize with profit.

\section{Literature}

Forgács Anna (2007): Részfolyamatok funkcionális kontrollingja - A logisztikai kontrolling alkalmazása egy külföldi nagyvállalat magyarországi elektronikai gyáregységében Ecovit - A controller, III. Évfolyam, július-augusztus 12. oldal

Halászné Sipos Erzsébet (1998): Logisztika szolgáltatások, versenyképesség, Logisztikai Fejlesztési Központ, Magyar Világ Kiadó

Knoll Imre (2003): Logisztika- gazdaság - társadalom, Kovásznai Kiadó, Budapest Hargitai Sándor (1996): Bevezetés a controlling gyakorlatába, JATE - ÁJK, Szeged

Körmendi Lajos - Tóth Antal (1998): Controlling a hazai szervezetek gazdálkodási gyakorlatában, WEKA Szakkiadó Kft, 